\title{
Economic Participation and National Self-Identification of Refugees in the Netherlands
}

\author{
De Vroome, T., Coenders, M., Van Tubergen, F., Verkuyten, M.
}

NOTE: post-print version, December 22, 2010

(post-refereeing, for information see: http://www.sherpa.ac.uk/romeo/issn/0197-9183/)

This article may not exactly replicate the final version published in the journal. It is not the copy of record.

The definitive version is available online:

De Vroome, T., Coenders, M., Van Tubergen, F., Verkuyten, M. (2011).

Economic Participation and National Self-Identification

of Refugees in the Netherlands.

International Migration Review, 45 (3), 615-638.

http://dx.doi.org/10.1111/j.1747-7379.2011.00860.x

\begin{abstract}
This study examines whether refugees self-identify as a member of the host society. We use survey data of more than 2,500 Somali, Iraqi, Afghani, Iranian and ex-Yugoslavian refugees in the Netherlands. The results show that economic participation in the host country is positively related to refugees' national self-identification. In addition, we find that refugees' social ties with Dutch natives are associated with national self-identification and the relationship between economic participation and national self-identification is partially explained by these social ties. Perceived discrimination is not related to refugees' national self-identification. Implications of these findings for debates on immigration and integration are discussed.
\end{abstract}




\section{Economic Participation and National Self-Identification of Refugees in the Netherlands}

\section{Introduction}

Even though refugees are a large and distinct group of immigrants in Western countries, less is known about their integration than of other immigrants (De Vroome \& Van Tubergen, 2010; Lamba, 2003; Waxman, 2001). Moreover, the research on refugees has mainly focused on their economic integration (Colic-Peisker, 2009; Connor, 2010; De Vroome \& Van Tubergen, 2010). Because of refugees' distinct motives for migration and their generally disadvantaged socio-economic position in host societies, it is interesting to find out whether refugees' self-identification as a member of the host society follows the same pattern found among other immigrants, and whether their socio-economic position in the host society affects their national self-identification.

We examine refugees' self-identification in terms of the act of defining oneself as a member of a particular social grouping (Ashmore, et al., 2004; Verkuyten, 2005). According to Ashmore and colleagues (2004), self-identification is the precondition for other dimensions of national identity, including feelings of belonging, commitment and attachment. National self-identification concerns identification of oneself as a member of the host society, which is a first and necessary step for identification with the host society (Verkuyten, 2005).

Immigrants' identification with the host society is a critical issue in public and scientific debates on immigrant integration (Phinney, 1990; Zimmermann et al., 2007). Some have claimed that immigrants' self-identification as a minority group member is coupled with a lack of identification with the host society which undermines the common bonds in society, while others have argued that identification with the ethnic minority group does not necessarily imply a lack of commitment to the host society. Research has shown that ethnic identification and national identification of immigrants are not necessarily mutually exclusive (Berry, 1997; Verkuyten, 2005; Zimmermann et al., 2007). Although our study is related to this research, we do not look at the strength of ethnic and national identification as two separate dimensions but focus on whether refugees self-identify as a member of the host society, as opposed to identification as a member of their ethnic origin group. In this manner, we focus on the factors that can stimulate identification with the host country among refugees.

Immigrants' economic participation in the host country is generally considered to be a critical determinant of host country identification (Alba \& Nee, 1997; Walters et al., 2007). Considering refugees' disadvantaged socio-economic position in host societies, the main aim of our study is to investigate how refugees' economic participation in the host country is related to their national self-identification.

In addition to economic participation, researchers have argued that immigrants' social integration and the perceived discrimination by the majority population play an important role in determining immigrants' national identification (Jasinskaja-Lahti, et al., 2009; Lubbers, et al. 2007; Verkuyten \& Yildiz, 2007). Therefore, we investigate to what extent refugees' social ties and perceived discrimination by the majority population affect their national self-identification. 
Furthermore, we examine the intermediate role of refugees' social ties for the relation between economic participation and national self-identification. We suggest that the relation between participation in the host country and national self-identification is partially mediated by refugees' social ties with natives. This means that social ties with natives can function as a mechanism that explains the relation between economic participation and national selfidentification. We argue that this mediating mechanism may be a valuable addition to studies on host country identification among immigrants in general.

Sociological studies on determinants of immigrants' host country identification are quite scarce (Walters et al., 2007; Zimmermann et al., 2007), and studies among refugees are even scarcer. Using a unique data set, we are able to examine the national self-identification of more than 2500 refugees from Afghanistan, Iran, Iraq, Somalia and the former Yugoslavia in the Netherlands. These are the largest groups of refugees who have been granted asylum in the Netherlands between the late 1970's and 2002. Large numbers of refugees from these countries have settled in many other destination countries as well (Hovy \& Chabake, 2005).

The political problems that forced most people of the current refugee groups out of their origin countries started in the late 1970's and early 1980's (Nafziger et al., 2000). In 1977, for instance, the Ogaden War between Somalia and Ethiopia started, after which the military dictatorship in Somalia became increasingly repressive and many Somali's fled their country (Nafziger et al., 2000). A second surge in the number of Somali refugees followed the civil war in the 1990's. Regarding the former Yugoslavia, the first migrants to the Netherlands were labour migrants. After Tito's death in 1980 ethnic tensions grew and already started to become a motive for fleeing the country up until the eruption of the Yugoslavian wars in the 1990s (Nafziger et al., 2000). Regarding Iran, Iraq and Afghanistan, there have been relatively large refugee flows since 1979-1980, when there was the Islamic Revolution in Iran, the start of the Iran-Iraq war and the invasion of Afghanistan by Russia (Nafziger et al., 2000).

\section{Theory and Hypotheses}

Previous research suggests that economic participation, discrimination by the majority population and social ties are important determinants of immigrants' national selfidentification (Nesdale, 2002; Walters et al., 2007; Zimmermann et al., 2007). We argue that these factors can also be relevant to the experience of refugees, and we propose that the economic position and social ties in the origin country should be considered in addition to economic participation and social ties in the host country.

\section{Economic position}

An influential assumption in the literature on immigrant integration is that participation in structures and institutions of the host society that directly (i.e. labour market) or indirectly (i.e. language, education system) relate to one's economic position, play a key role in stimulating other forms of integration, such as identification with the host community (Gordon, 1964). Economic participation in the host country is thought to nurture a sense of achievement, self-esteem and belonging, which can translate into a positive attitude towards the host society (Hagendoorn, et al., 2003). Following this argument, it can be expected that economic participation in the host country stimulates refugees' national self-identification. 
We therefore hypothesize that higher economic participation in the host country (i.e. education, employment and occupational status in the host country and proficiency in the host country language) increase refugees' self-identification as Dutch (H1).

Pre-immigration economic factors, such as education in the country of origin, can also affect the national self-identification of immigrants (Zimmermann et al., 2007). The skills and knowledge that 'secured' a certain socio-economic position in the origin country may not be easily transferable to the host country, especially for refugees (De Vroome \& Van Tubergen, 2010; Friedberg, 2000; Kanas \& Van Tubergen, 2009). Moreover, education in the country of origin represents a period of socialization in childhood and/or adolescence which can have a lasting effect on refugees' sense of ethnic belonging. It can thus be expected that the education in the origin country stimulates ethnic rather than national self-identification. We therefore hypothesize that a higher level of education in the origin country will be negatively related to refugees' self-identification as Dutch $(\mathrm{H} 2)$.

\section{Social Ties}

Researchers have argued that the social integration of immigrants forms an important explanation of immigrants' host country identification (Lubbers, et al., 2007). The main argument is that interaction with others in social networks contributes to a sense of belonging. Social ties can function as a basis for self-identification and group membership because immigrants will tend to consider themselves as members of the same group as their (close) social ties. It can be argued that, consequently, social ties with co-ethnics will foster self-identification as a member of the ethnic minority group (Lubbers et al., 2007). In contrast, social ties with natives (i.e. social integration) will foster host country identification (Nesdale, 2002). Based on these arguments, we hypothesize that social ties with natives (i.e. having Dutch friends, being a member of a Dutch organization, having more contact with natives than with co-ethnics) is positively related to refugees' self-identification as Dutch (H3).

In addition to the social ties with natives and co-ethnics in the host country, we consider the partner, children, and other social ties that refugees may have left behind in the origin country, or who have moved to another country than the Netherlands. Similar to social ties with co-ethnics in the host country, social ties in the country of origin are expected to stimulate self-identification in terms of the ethnic group, rather than self-identification as a member of the host society. We thus hypothesize that social ties in the origin country (i.e. having a partner or children in the origin country and sending remittances) is negatively related to refugees' self-identification as Dutch (H4).

Finally, we suggest that social ties can function as a mechanism that partially explains why refugees' economic participation in the host country can affect their national selfidentification. We propose this mechanism because the literature is rather unclear about why exactly there would be a relationship between economic participation and national selfidentification. As noted earlier, one explanation in the literature is that economic participation in the host country nurtures a sense of achievement in the host society and acceptance by the majority population, which can translate into a positive attitude towards the host society (Hagendoorn, et al., 2003). We argue that education and employment in the host country and proficiency in the host country language can also facilitate refugees' contact opportunities 
and interactions with natives. In turn, these social ties can lead to a stronger sense of belonging to the national category. This means that by increasing social ties with natives, refugees' economic participation in the host country might indirectly increase the likelihood of refugees' national self-identification. We thus hypothesize that refugees' economic participation in the host country increases refugees' social ties with native Dutch, and these increase refugees' self-identification as Dutch (H5).

\section{Perceived Discrimination}

In addition to economic participation, the perceived acceptance by the majority population might play an important role in immigrants' national self-identification (Hwang \& Murdock, 1991; Nesdale, 2002; Ono, 2002). Research in sociology and social psychology suggests that perceived discrimination, or perceived rejection by members of the majority population, is an important explanation of national (dis)identification (Ono, 2002; Verkuyten \& Yildiz, 2007). The underlying mechanism of the relation between perceived discrimination and national (dis)identification is well described in the social psychological literature. According to social identity theory (Tajfel \& Turner, 1986) and the related rejection-identification model (Branscombe, Schmitt \& Harvey, 1999), discrimination is a negative experience that strengthens ethnic identification of minorities. It presents a threat to group identity, making people increasingly turn toward the safety and acceptance of their minority group and away from the discriminating majority group.

Recently, the rejection-identification model has been extended to the rejectiondisidentification model, which suggests that perceived discrimination not only leads to increased identification with one's minority group, but also prevents minorities from developing national identification with the host country (Jasinskaja-Lahti, et al., 2009; Verkuyten \& Yildiz, 2007). Because the refugees from the origin countries in our study are often distinct from native Dutch in their physical appearance and cultural expressions, and because native Dutch will tend to perceive a 'cultural distance' between these groups and the majority group, refugees are also likely to encounter and perceive discrimination in Dutch society. The perception of being discriminated against can be expected to decrease the likelihood of national self-identification among refugees. We hypothesize that perceived discrimination is negatively related to refugees' self-identification as Dutch (H6).

\section{Data and Methods}

\section{Data}

According to the 2003 UNHCR statistical yearbook, the refugee groups included in our study were the largest groups of refugees in the Netherlands in 2003, with about 8000 Iranian, 14000 Somali, 26000 Afghan, and 29000 Iraqi refugees and about 20000 refugees from the former Yugoslavia (Hovy \& Chabake, 2005). We base our analysis on the SPVA (Social Position and Use of Provisions by Ethnic Minorities) survey data, collected in 2003 by Veldkamp research and commissioned by the Netherlands Institute for Social Research (SCP). The purpose of the survey was to gain more insight into the socio-economic position of refugee groups in the Netherlands. The survey data includes a cross-section of more than 
3500 people who are born in Afghanistan, Iran, Iraq, Somalia, or the former Yugoslavia (Schothorst, 2004).

The respondents were randomly selected from municipal records in twelve larger cities in the Netherlands. The fieldwork was done using Computer Assisted Personal Interviewing (CAPI) in the Dutch, English, or French language. Response rates of the groups were between 43\% (former Yugoslavians) and 55\% (Afghans). The reasons for non-response showed a similar pattern across the refugee groups, the most important being that about $25 \%$ of the people refused cooperation, about $15 \%$ could not be contacted at the time of data collection, and about $5 \%$ could not participate because of language difficulties. Other reasons of non-response include respondents for whom the address was incorrect and those who were in very bad health or had passed away. Analysis of the data shows that the distribution of the sample across age and gender strongly resembles that of the respective refugee populations. Moreover, the distribution across cities of residence is similar between the sample and the population (Schothorst, 2004).

Because of the sampling method used - respondents were selected on the basis of their country of birth - a minority of the respondents has migrated to the Netherlands for other reasons than seeking refuge. When asked to indicate their primary motive for migration, 86 per cent of the respondents mentioned reasons such as 'political suppression' and 'war/violence', and 14 per cent of the respondents mentioned reasons that relate to finding work and family formation and reunification. Because we want to focus our study on refugees, we excluded the latter group of respondents from the sample. It should be noted that most of the work and family migrants that are excluded in our analyses were born in the former Yugoslavia and came to the Netherlands before the 1980s. Furthermore, we have selected respondents between the ages of 18 and 65, and we have excluded a small number of respondents who were born in the Netherlands or who were younger than age six at the time of migration. We thus focus on the foreign born adult respondents. The people with missing information on one or more of the independent variables (3\%) are also excluded from the analyses. The total number of respondents for our analyses is 2516 .

\section{Dependent Variable}

National self-identification was measured with a two-step procedure. Respondents were asked the question 'Do you see yourself as an <ethnic origin group >? (e.g. Afghan)'. When respondents responded negatively, they were asked to which group they felt they did belong. Part of the respondents replied with stating 'Dutch', while other respondents indicated that their primary identification was centred on an ethnic subgroup (e.g. Pashtun). A small minority of respondents answered 'don't know' (7\%) or 'other, namely ...' (3.9\%) followed with a variety of self-identifications. With these two questions, we have created a measure indicating whether or not refugees (primarily) categorize themselves as Dutch. For our main analyses, we excluded the people who answered 'don't know' or 'other, namely..' from the sample. In our analyses, we contrast the respondents who categorize themselves as Dutch (1) with the respondents who categorize themselves as a member of an ethnic origin group (0). Our analyses are based on a sample of 2516 respondents. We have conducted additional analyses (not discussed in this paper), in which we contrasted the respondents who categorize themselves as Dutch (1) with the respondents who categorize themselves as a member of an 
ethnic group (2) and the respondents who answered 'don't know' (3) or 'other, namely..' (4). The results of these additional analyses yielded the same substantive conclusions. ${ }^{1}$

\section{Independent Variables}

We operationalize economic position in the host country by looking at refugees' postmigration education, proficiency in the host country language, employment, and occupational status. With respect to education in the host country, respondents were asked if they had acquired education in the Netherlands. We use a binary variable, contrasting respondents who had acquired education in the Netherlands (1) to those who did not (0). The measure for Dutch language proficiency is based on the assessment of the interviewer, who rated the respondent's language proficiency on a three point scale ranging from good to bad. In the analyses, we have contrasted the respondents with good Dutch language proficiency (1) with respondents with reasonable and bad language proficiency (0). Regarding employment, respondents were asked if they were currently employed. Those who were currently employed (1) are contrasted with unemployed people, including those who are and those who are not 'seeking' employment (0). All respondents who were employed have described their occupation. We have recoded the respondents' occupation into the International SocioEconomic Index (ISEI), which is an internationally comparable measure of occupational status (Ganzeboom, et al., 1992). ISEI scores represent a continuous approach to occupational stratification and reflect a weighted sum of the average education and average income of occupational groups (Ganzeboom, et al., 1992). To illustrate, office cleaners and farm workers have a score around 20, nursing personnel a score around 40, and lawyers and medical doctors have a score around 85 . We use the ISEI scores, ranging from 16 to 88 , as a measure of occupational status. Because we also include a dummy variable for employment, unemployed respondents were given the mean score. In this way the unemployed do not influence the effect of occupational status. Regarding refugees' economic position in the origin country, we include a variable for refugees' education in the origin country. We use a measure indicating the highest type of education in which the respondent has been enrolled in the country of origin. The measure includes five categories ranging from no education at all, through primary education and lower and higher secondary education, to tertiary education.

To measure social ties with natives, we use three measures of the extent to which refugees' social networks include members of the majority population. First, respondents were asked to indicate if they have any Dutch friends. We have contrasted respondents who do not have any Dutch friends (0) with those who do have Dutch friends (1). The second measure is organizational membership. Respondents have indicated whether or not they were a member of an organization. The organizations may include any kind of association, such as sports, community, and political organizations. Only about $1 \%$ of the reported organizational memberships were with an ethnic organization, and these are not included as an organizational membership. We have contrasted respondents who are member of one or more organizations (1) with respondents who have no organizational memberships (0). Third, we have included a dummy variable for the composition of contacts with the Dutch majority and with members of the ethnic minority group. Respondents were asked to indicate if they had more Dutch social contacts than co-ethnic, more co-ethnic contacts than Dutch, or an equal amount of contacts from both groups. Respondents who indicated having more co-ethnic than 
Dutch contacts $(0)$ are contrasted with those who indicate that they have an equal amount of Dutch and co-ethnic contacts and those who indicate having more Dutch than co-ethnic social contacts (1).

Regarding social ties in the origin country, we look at whether the respondents have a partner or child(ren) in the country of origin and whether the respondents send remittances. For having children, we include dummy variables contrasting respondents who have no children (1), respondents who only have children in the Netherlands (2), respondents who only have children in the origin country (3), and respondents who have children in both the origin country and the Netherlands (4). Regarding having a partner, we include dummy variables contrasting respondents who do not have a partner (1), respondents who have a coethnic partner in the Netherlands (2), respondents who have a partner in the origin country or another country that is not the Netherlands (3), respondents who have a Dutch partner (4), and respondents who have a partner in the Netherlands with another (third) ethnicity (5). For remittances, we include a dummy variable contrasting respondents who do send remittances (1) to respondents who do not send remittances (0).

Regarding perceived discrimination, we look at refugees' perceived personal discrimination and group discrimination. First, respondents have indicated their perception of personal discrimination, rated on a five-point scale ranging from 'never discriminated against' to 'very often discriminated against'. Second, respondents have indicated whether they have the impression that their ethnic group (e.g. Somalis) is being discriminated against, also on a five-point scale ranging from 'never' to 'very often'. There is a significant correlation between the answers to the two questions of group and personal discrimination $(\mathrm{r}=.68, \mathrm{p}<.01)$. Therefore, we created one variable for perceived discrimination, with a fivepoint scale ranging from 'never discriminated against' to 'very often discriminated against', based on the average of the two questions. ${ }^{2}$

Finally, we include several background variables that have been found to affect national identification in previous research on immigrants, or that might be relevant for the specific situation of refugees (Walters et al., 2007; Zimmermann et al., 2007). About 74\% of the refugees in our sample have the Dutch nationality, and the other $26 \%$ of the respondents have residence documents that guarantee their legal residence in the Netherlands for at least five years (after which it is sometimes necessary to apply for an extension). We therefore control for legal citizenship in our analyses by including dummy variables that contrast refugees who only have the Dutch nationality (1) to refugees who have the Dutch and another nationality (2) and refugees who only have a foreign nationality (3). We also include dummy variables representing the country of origin (i.e. Somalia, Afghanistan, Iraq, Iran, and the former Yugoslavia). We further control for the effects of gender, age at migration and duration of stay in the Netherlands. The descriptive statistics for the dependent and independent variables are presented in Table 1. 
Table 1. Descriptive Statistics of Dependent and Independent Variables, $\mathrm{N}=2516$

\begin{tabular}{|c|c|c|c|}
\hline & Range & Mean & SD \\
\hline \multicolumn{4}{|l|}{ Dependent variable } \\
\hline Self-identification as Dutch & $0 / 1$ & 0.198 & \\
\hline \multicolumn{4}{|l|}{ Independent Variables } \\
\hline \multicolumn{4}{|l|}{ Economic Opportunities } \\
\hline Employed & $0 / 1$ & 0.428 & \\
\hline Occupational status & $16-88$ & 39.506 & 9.908 \\
\hline High Dutch language proficiency & $0 / 1$ & 0.638 & \\
\hline Education in the Netherlands & $0 / 1$ & 0.266 & \\
\hline Education in the origin country & $0-4$ & 2.205 & 1.321 \\
\hline \multicolumn{4}{|l|}{ Social Ties } \\
\hline Native friends & $0 / 1$ & 0.727 & \\
\hline Member of an organization & $0 / 1$ & 0.144 & \\
\hline Composition contacts (half/mainly natives) & $0 / 1$ & 0.591 & \\
\hline \multicolumn{4}{|l|}{ Children } \\
\hline Only children in the Netherlands & $0 / 1$ & 0.504 & \\
\hline Only children in origin country & $0 / 1$ & 0.054 & \\
\hline Children in origin country and in the Netherlands & $0 / 1$ & 0.049 & \\
\hline No children & $0 / 1$ & 0.393 & \\
\hline \multicolumn{4}{|l|}{ Partner } \\
\hline Co-ethnic partner in the Netherlands & $0 / 1$ & 0.460 & \\
\hline Partner in origin country or third country & $0 / 1$ & 0.076 & \\
\hline Dutch partner & $0 / 1$ & 0.019 & \\
\hline Partner with other ethnicity in the Netherlands & $0 / 1$ & 0.026 & \\
\hline No partner & $0 / 1$ & 0.420 & \\
\hline Sends remittances & $0 / 1$ & 0.311 & \\
\hline \multicolumn{4}{|l|}{ Perceived Discrimination } \\
\hline Perceived personal and group discrimination & $0-4$ & 0.815 & .868 \\
\hline \multicolumn{4}{|l|}{ Control Variables } \\
\hline \multicolumn{4}{|l|}{ Nationality } \\
\hline Dutch nationality only & $0 / 1$ & 0.668 & \\
\hline Dutch and foreign nationality & $0 / 1$ & 0.076 & \\
\hline Foreign nationality only & $0 / 1$ & 0.256 & \\
\hline \multicolumn{4}{|l|}{ Country of origin } \\
\hline Afghanistan & $0 / 1$ & 0.231 & \\
\hline Iraq & $0 / 1$ & 0.222 & \\
\hline Iran & $0 / 1$ & 0.187 & \\
\hline Former Yugoslavia & $0 / 1$ & 0.141 & \\
\hline Somalia & $0 / 1$ & 0.216 & \\
\hline Male & $0 / 1$ & 0.706 & \\
\hline Age at migration & 6-57 & 26.977 & 9.561 \\
\hline Years of residence in the Netherlands & $1-28$ & 9.530 & 3.219 \\
\hline
\end{tabular}

Source: Own calculations (SPVA, 2003).

\section{Results}

First we describe some demographic group differences between the groups of refugees (see Table 2). Most of the refugees in our sample are male, but more than half of the refugees from Somalia are female. Considering the age at migration, refugees from Somalia stand out with a mean age at migration of around 22, which is substantially lower than the average age at migration in the other groups (around 28). Table 2 also shows that, on average, the refugees from Afghanistan and Iraq have lived in the Netherlands for less than ten years, while the average length of residence in the Netherlands for the refugees from Iran, Somalia and the former Yugoslavia is ten years or more. 
Table 2. Demographic details by refugees' country of origin

\begin{tabular}{|c|c|c|c|c|c|}
\hline & \multirow{2}{*}{$\begin{array}{l}\text { Male } \\
\text { Mean }\end{array}$} & \multicolumn{2}{|c|}{ Age at Migration } & \multicolumn{2}{|c|}{$\begin{array}{l}\text { Years of residence in } \\
\text { the Netherlands }\end{array}$} \\
\hline & & Mean & SD & Mean & SD \\
\hline \multicolumn{6}{|l|}{ Country of origin } \\
\hline Afghanistan & .843 & 28.378 & 10.116 & 7.550 & 2.892 \\
\hline Iraq & .826 & 28.731 & 9.016 & 8.840 & 2.640 \\
\hline Iran & .730 & 28.234 & 8.602 & 11.580 & 3.493 \\
\hline Former Yugoslavia & .603 & 27.603 & 9.897 & 10.080 & 2.667 \\
\hline Somalia & .484 & 22.215 & 8.501 & 10.220 & 2.702 \\
\hline
\end{tabular}

Source: Own calculations (SPVA, 2003).

To analyse the relationship between refugees' economic position and national selfidentification, and the role of refugees' social ties and perceived discrimination, we have used a stepwise approach with two models. Model 1 includes the variables that are related to refugees' economic participation in the host country and economic position in the origin country (i.e., post-migration education, Dutch language proficiency, employment and occupational status in the host country, and education in the country of origin), and perceived discrimination. Model 2 includes the variables for social ties (i.e. Dutch friends and organizational membership, relative frequency of contact with natives, location of the partner and children, sending remittances). We use this approach because it facilitates the testing of the hypotheses on direct relations and on the role of social ties with natives as a mediator of the relationship between refugees' economic position in the host country and national selfidentification. We use binary logistic regression to estimate our models. The results of these analyses are presented in Table 3. In addition, we use Sobel tests of mediation to determine whether the mediating (i.e. indirect) relationships are statistically significant.

\section{Economic Position}

We hypothesized that higher economic participation in the host country (i.e., Dutch education, proficiency in the Dutch language, employment and economic status in the Netherlands) is positively associated with refugees' self-identification as Dutch (H1). Results show that employment is indeed significantly and positively related to national selfidentification. Refugees who are employed have about $1.3\left(e^{.279}\right)$ times higher odds of identifying themselves as Dutch (Table 3, Model 1). In addition, occupational level is also significantly and positively related to national self-identification. One standard deviation increase in occupational status is associated with $1.1\left(e^{.009^{*} 9.908}\right)$ times higher odds of selfidentification as Dutch (Table 2, Model 1). Furthermore, Dutch language proficiency is significantly and positively related to national self-identification. Refugees who have high proficiency in the Dutch language have about 1.6 times higher odds of self-identifying as Dutch, other things being equal (Table 3, Model 1). However, it turns out that education in the Netherlands is not significantly related to national self-identification (Table 3).

Our second hypothesis stated that a higher level of education in the origin country is negatively related to refugees' self-identification as Dutch (H2). In line with this hypothesis, results show that one standard deviation increase in educational level in the origin country is associated with 1.3 times lower odds of self-identification as Dutch (Table 3, Model 1). 
Table 3. Logistic Regression Analyses of Refugees' National Self-Identification

\begin{tabular}{|c|c|c|c|c|}
\hline & \multicolumn{2}{|c|}{ Model 1} & \multicolumn{2}{|c|}{ Model 2} \\
\hline & B & se & B & se \\
\hline \multicolumn{5}{|l|}{ Economic Opportunities } \\
\hline Employed & $0.279 *$ & .117 & 0.187 & .124 \\
\hline Occupational status & $0.009^{*}$ & .005 & 0.007 & .005 \\
\hline High Dutch language proficiency & $0.448^{*}$ & .129 & $0.310^{*}$ & .135 \\
\hline Education in the Netherlands & 0.170 & .123 & 0.161 & .126 \\
\hline Education in the origin country & $-0.218 * *$ & .046 & $-0.239 * *$ & .048 \\
\hline \multicolumn{5}{|l|}{ Social Ties } \\
\hline Dutch friends & & & $0.255^{*}$ & .153 \\
\hline Member of an organization & & & 0.189 & .143 \\
\hline Composition contacts (half/mainly natives) & & & $1.063 * *$ & .134 \\
\hline \multicolumn{5}{|l|}{ Children } \\
\hline Only children in the Netherlands (ref.) & & & 0 & \\
\hline Only children in origin country & & & -0.113 & .288 \\
\hline Children in origin country and in the Netherlands & & & $-1.025 *$ & .354 \\
\hline No children & & & 0.011 & .135 \\
\hline \multicolumn{5}{|l|}{ Partner } \\
\hline Co-ethnic partner in the Netherlands (ref.) & & & 0 & \\
\hline Partner in origin or third country & & & -0.193 & .266 \\
\hline Dutch partner & & & $0.788^{*}$ & .327 \\
\hline Partner with other ethnicity in the Netherlands & & & 0.115 & .319 \\
\hline No partner & & & 0.097 & .132 \\
\hline Sends remittances & & & $-0.246^{*}$ & .127 \\
\hline \multicolumn{5}{|l|}{ Perceived Discrimination } \\
\hline Perceived personal and group discrimination & -0.056 & .061 & -0.043 & .063 \\
\hline \multicolumn{5}{|l|}{ Control Variables } \\
\hline \multicolumn{5}{|l|}{ Nationality } \\
\hline Dutch nationality only (ref.) & 0 & & 0 & \\
\hline Dutch and foreign nationality & $-0.702 *$ & .217 & $-0.599 *$ & .222 \\
\hline Foreign nationality only & $-0.348 *$ & .147 & $-0.434 *$ & .152 \\
\hline \multicolumn{5}{|l|}{ Country of origin } \\
\hline Afghanistan (ref.) & 0 & & 0 & \\
\hline Iraq & -0.103 & .159 & -0.068 & .165 \\
\hline Iran & $0.388 *$ & .168 & 0.206 & .175 \\
\hline Former Yugoslavia & -0.014 & .179 & -0.109 & .186 \\
\hline Somalia & $-0.644 * *$ & .184 & $-0.432 *$ & .190 \\
\hline Male & -0.073 & .123 & -0.043 & .131 \\
\hline Age at migration & $0.017 *$ & .006 & $0.029 * *$ & .007 \\
\hline Years of residence in the Netherlands & 0.025 & .020 & 0.018 & .020 \\
\hline Constant & $-2.161 * *$ & .353 & $-3.059 * *$ & .405 \\
\hline chi $^{2}$ model & \multicolumn{2}{|l|}{114} & \multicolumn{2}{|l|}{238} \\
\hline Df & \multicolumn{2}{|l|}{15} & \multicolumn{2}{|l|}{26} \\
\hline $\mathrm{p}\left(\mathrm{chi}^{2}\right)$ & \multicolumn{2}{|c|}{0.001} & \multicolumn{2}{|c|}{0.001} \\
\hline Nagelkerke $\mathrm{R}^{2}$ & \multicolumn{2}{|c|}{0.070} & \multicolumn{2}{|c|}{0.143} \\
\hline $\mathrm{N}$ & \multicolumn{2}{|c|}{2516} & \multicolumn{2}{|c|}{2516} \\
\hline
\end{tabular}

Source: Own calculations (SPVA, 2003).

Notes: ${ }^{*} \mathrm{p}<.001 ;{ }^{*} \mathrm{p}<.05$ (one-tailed test for hypothesized effects, two-tailed test otherwise). The Nagelkerke $\mathrm{R}^{2}$ is a pseudo $\mathrm{R}^{2}$ measure for logistic regression models, and it is calculated by dividing the Cox \& Snell pseudo $R^{2}$ by the maximum value of the Cox and Snell pseudo $R^{2}$ (Nagelkerke, 1991).

\section{Social Ties and Perceived Discrimination}

We hypothesized that refugees who have more social ties with natives will be more likely to self-identify as Dutch (H3). In line with this hypothesis, the results show that having Dutch friends is positively related to national self-identification. In contrast with refugees who do not have Dutch friends, those who do have Dutch friends are about 1.3 times more likely to 
self-identify as Dutch. Results also show that a relatively high number of contacts with native Dutch is positively and significantly related to national self-identification. In contrast with refugees who have only or mainly social ties with co-ethnics, refugees whose social ties are equally divided between native Dutch and co-ethnics or who have more contact with native Dutch than with co-ethnics have about 2.9 times higher odds of self-identification as Dutch, other things being equal (Table 3, Model 2). From the results in Table 3, it appears that organizational membership is unrelated to national self-identification.

We also hypothesized that refugees who have more social ties in the origin country are less likely to self-identify as Dutch (H4). The evidence for this hypothesis is mixed. Having a partner abroad does not significantly affect refugees' national self-identification, when contrasted with refugees who have a co-ethnic partner in the Netherlands. Our fourth hypothesis is to some extent confirmed, namely for the effect of having children. Results show that when contrasted with having only children in the Netherlands, having children in the origin country as well as in the Netherlands, but not having children in the origin country only, is significantly and negatively related to refugees' odds of self-identifying as Dutch. Having children in the origin country as well as in the Netherlands is associated with about 2.9 times lower odds of self-identification as Dutch. Our fourth hypothesis is supported by the results for sending remittances. As expected, refugees who send remittances are about 1.3 times less likely to self-identify as Dutch (Table 3, Model 2).

Furthermore, we hypothesized that the effects of economic participation in the host country on national self-identification would be (partially) mediated by refugees' social ties with natives (H5). The critical test for mediation is that the influence of the predictor (economic participation) on the dependent variable (national self-identification) is substantially reduced when the mediator (social ties) is added as a predictor (see Baron \& Kenny, 1986). The results provide some evidence for this mediating hypothesis. Employment and occupational status in the Netherlands do no longer significantly affect national selfidentification when the measures for social ties are introduced in the second model, and the relation between Dutch language proficiency and national self-identification is also reduced (table 3, model 2). Sobel tests of mediation show that there are two significant mediation effects, both in which refugees' composition of contacts (i.e. whether half or more of refugees' contacts are natives) is the mediating variable. The indirect effect of employment, through refugees' social contacts, on national self-identification is positive and significant $(\mathrm{Z}=2.668, \mathrm{p}=.004)$. The indirect effect of language proficiency, through refugees' composition of contacts, on national self-identification is also significant $(Z=2.591, p=.005)$. The relationships between employment and national self-identification and between language proficiency and national self-identification are thus partially explained by the composition of refugees' social contacts. This supports the proposition that refugees' economic participation in the Netherlands is related to national self-identification because it increases refugees' social ties with natives. Sobel tests of mediation show that there are no significant mediation effects for the relationships between refugees' occupational status and national selfidentification, and between refugees' education in the Netherlands and national selfidentification.

We further hypothesized that refugees who perceive more discrimination would be less likely to self-identify as Dutch (H6). Our results show, however, that perceived 
discrimination does not significantly affect refugees' self-identification as Dutch (table 3, model 1 and 2).

Finally, some of the results for the control variables warrant discussion. First, the differences between ethnic groups are rather large in our first model. Especially Somali respondents have lower odds of identifying themselves as Dutch, in contrast to the other refugee groups. In our second model, the contrasts between the refugee groups are smaller. This indicates that the differences in national self-identification between refugee groups can be partially explained by taking the social ties in the origin country, host country and third countries into account. Furthermore, having Dutch legal citizenship is associated with higher odds of self-identification as Dutch, in contrast with refugees who do not have Dutch citizenship. Having double citizenship is also associated with lower odds to self-identify as Dutch, in contrast with refugees who only have Dutch citizenship. There are no gender differences in national self-identification. Finally, while also taking into account the duration of residence in the Netherlands, age at migration is positively and significantly related to identification as Dutch: refugees who were older when they came to the Netherlands are more likely to self-identify as Dutch. While this is somewhat counterintuitive, it should be noted that factors that explain (away) the negative effects of age at migration on national selfidentification (e.g., education, language, and contacts) are simultaneously included in the model. $^{3}$

\section{Discussion}

In many countries the question of immigrants' commitment to the nation is raised, and worries are expressed about fragmentation or a decline in national unity and social cohesion, due to immigrants maintaining their loyalty towards the origin country. We have examined the national self-identification of more than 2500 foreign born Somali, Iraqi, Afghani, Iranian and ex-Yugoslavian refugees in the Netherlands. The aim of this study was to investigate the role of economic participation in the host country in fostering refugees' national selfidentification. In addition, we argued that refugees' social ties with natives and with people in the country of origin, as well as the perceived discrimination by natives, might be important determinants of refugees' self-identification as a member of the host society.

This article presents one of the first studies on the national self-identification of refugees and extends insights from research on ethnic and national self-identification of immigrants in general (e.g., Berry, 1997; Verkuyten \& Yildiz, 2007; Zimmermann et al., 2007). Because of refugees' specific migration motives and disadvantaged socio-economic position in the host society, it is interesting to find out whether refugees' self-identification as a member of the host society follows the same pattern and is affected by the same factors as among other immigrants.

The results show that among refugees in the Netherlands, economic participation in the host country does foster national self-identification. We find that language proficiency, employment and occupational status are positively related to national self-identification. Our results thus support the assumption that refugees' economic integration fosters identification with the host country. These results differ from previous studies on identification among immigrants that find no significant effects of post-migration education and economic success in the host country on national identification (Walters et al., 2007; Zimmermann et al., 2007). 
In line with our study, however, research by Nesdale (2002) in Australia has shown that immigrants' occupational status is positively related to host country identification. These contrasting findings suggest that the relationship should be investigated in more detail. In this study, we did so by analysing the role of social ties with natives as an intermediate factor.

Next to economic integration in the host country, we also studied the economic position in the origin country. In contrasts to previous research on immigrant identification (Zimmerman et al., 2007) we find that education in the origin country is important in explaining refugees' national self-identification. Among refugees in the Netherlands, the economic position in the origin country appears to promote self-identification in terms of the ethnic origin group, rather than national self-identification. The negative relation between educational level in the origin country and national self-identification lends support to the argument that refugees' pre-migration human capital skills (e.g. educational qualifications) yield little reward in the Netherlands, which is a problem that can negatively affect refugees' national self-identification (Kanas \& Van Tubergen, 2009).

Regarding social ties, we find that having relatively more Dutch social ties is positively correlated with national self-identification. These results support previous research on national identification, which also shows that having social contacts with natives contributes to identification with the host society (Walters et al., 2007). Our results also partially support the notion that having more ties in the country of origin is negatively related to refugees' self-identification as Dutch. This indicates that it is important to take transnational social ties into account in understanding refugees' national self-identification. It is likely that these ties are also important for immigrants in general (Lubbers et al., 2007; Nesdale, 2002).

Furthermore, we showed that the relationship between refugees' economic participation in the host country and national self-identification is partially mediated by refugees' social ties with natives. This suggests that these ties are a mechanism that explicates how economic integration in the host country promotes national self-identification, namely by increasing refugees' social contacts with natives. The notion that economic integration in the host country may indirectly foster host country identification, through more social ties with natives, may also be useful in research on ethnic and national identification of immigrants in general. The mechanism of social ties comes in addition to other mechanisms that can explain the relation between immigrants' economic integration and host country identification that have been described in the literature. For example, there is the notion that economic integration nurtures a sense of achievement and of acceptance by the majority which in turn leads to a positive attitude towards the host society and increased host country identification (Hagendoorn, et al., 2003). Our study indicates that employment stimulates national self-identification when the occupation provides opportunities for contact with natives. Unfortunately, the weak economic position of refugees in the Netherlands - with high unemployment and low occupational status among the employed (De Vroome \& Van Tubergen, 2010) - implies that refugees' contact opportunities with natives are hampered by unemployment and work in low-paying sectors of the Dutch labour market in which immigrants are predominantly employed.

Unexpectedly, the findings show that perceived discrimination is not independently related to refugees' national self-identification. This result contradicts the findings in 
previous research on the identification of immigrants (e.g., Nesdale, 2002; Verkuyten \& Yildiz, 2007) and does not support the rejection-disidentification model (Jasinskaja-Lahti, et al., 2009). One likely explanation is that the reported levels of discrimination are quite low (averaging below 1 on a scale between 0 and 4) which indicates that most respondents did not perceive any or much discrimination. Other studies in the Netherlands have shown that levels of perceived discrimination are much lower among refugees compared to other immigrant groups (Gijsberts, 2005). One explanation is the difference in migration motive. Refugees, who often have left their origin country because of violence and political suppression, may perceive the social context in the destination country as less negative than labour migrants. Moreover, in a study among refugees in Australia there were higher levels of perceived discrimination but these perceptions were not related to dissatisfaction with Australian society (Fozdar \& Torezani, 2008). This suggests that even when levels of perceived discrimination among refugees are higher, the extent to which they reduce their orientation towards the host society may be limited. A likely reason is that refugees evaluate their current situation more positively than the situation in their origin country.

Our measurement of national self-identification has some limitations. First, it should be noted that the sequence of the two identification questions creates a bias towards selfidentification as a member of an ethnic origin group because the participants were first asked whether they see themselves as a member of their ethnic group. It is likely that national selfidentification would have been higher on an open-ended question. A second and related limitation of our measure of national self-identification is that it does not reflect the widely accepted notion that immigrants' identity is better understood as two-dimensional (i.e. dual or hyphenated identities that combine identification with the national community and with the ethnic group) than as one-dimensional (i.e. identification with either the host society or the ethnic origin group) (Berry, 1997; Verkuyten, 2005; Zimmermann et al., 2007). Thus, the measure used limits the conclusions that we can draw. However, about $20 \%$ of the refugees in this study did self-identify as Dutch. Moreover, empirical research among Turkish immigrants in the Netherlands has shown that self-labelling in terms of a dual identity (e.g. Turkish-Dutch or Dutch-Afghan) is quite uncommon in the Netherlands, and that ethnic identification is negatively related to national identification (Verkuyten \& Yildiz, 2007). Thus, although we were unable to assess hyphenated identities, it is likely that our conclusions for the determinants of national self-identification will also hold for a twodimensional measure of self-identification.

Third, because national self-identification is measured at the same time as the other variables (i.e. we have cross-sectional data), we can only test for significant associations. Panel data are needed to test for causation because it is also possible that, for example, social contacts with native Dutch improve economic integration rather than the other way around. Despite the limitations of the data, we believe that this study provides novel and important insights into the national self-identification of refugees.

Although not the main focus of our study, the findings for some of the control variables should be noted. First, we found that citizenship is related to refugees' selfidentification. While nationality is especially relevant to the experience of refugees, nationality and citizenship status can be an issue in the immigration experience of other immigrants as well. Our study suggests that this is important to take into account in research 
on ethnic and national identification. Second, we show that there are differences in the odds of national self-identification between refugees from different origin countries, and that these differences are to some extent explained by refugees' social ties. Interestingly however, not all differences in national identification between the refugee groups are accounted for. There are various possible explanations of why refugees from Somalia are less inclined to selfidentify as Dutch compared to refugees from Afghanistan and Iran, such as differences in the size of the groups, residential segregation, migration patterns and transnational networks. Another possible explanation is the group difference in visibility (Colic-Peisker, 2009). The relatively high visibility of the predominantly black Somali group means that they stand out more in the predominantly white Dutch society. Though these explanations are beyond the scope of this study, it will be interesting to investigate them in future research.

In conclusion, our study provides support for the assumption that economic participation in the host country is positively related to refugees' national self-identification. In addition, we found that social ties with natives and social ties in the origin country are correlated with national self-identification, and that the relationship between economic participation in the host country and national self-identification is partially mediated by refugees' social ties with natives. These findings have implications for the on-going immigration and integration debates in many societies. They suggest that, among refugees, economic and social integration stimulate a sense of belonging to the host society. More specifically, economic integration seems to increase the opportunities to have contacts with members of the native population and these contacts, in turn, stimulate the identification of oneself as a member of the host society. Thus, concerns about immigrants' loyalty to the nation and the fragmentation of society due to immigrants' lack of host country identification might be addressed by improving their economic participation and social integration. In addition, a higher level of education in the country of origin was associated with lower national self-identification. This suggests that for developing a sense of belonging it is important that immigrants' skills and knowledge obtained in the country of origin are recognized in the host society. This study focused on explaining differences in national selfidentification between refugees within the Netherlands. Researchers have noted that the tone in Dutch political debate on immigration has become harsher since the 1990s, and that Dutch policy moved away from the model of multiculturalism (Koopmans, 2003). Cross-national studies or panel data are needed to assess how contextual factors like political climate and integration policies affect host country identification among refugees, which would be an interesting question for future research. 


\section{Notes}

${ }^{1}$ The results of the additional analyses are available upon request from the authors.

${ }^{2}$ Analyses with two separate variables for perceived personal discrimination and perceived group discrimination lead to the same substantive conclusions. Results of these analyses are available upon request from the authors.

${ }^{3}$ In a model including only country of origin and age at migration, the effect of age at migration is negative (results available from the authors upon request). When factors that explain (away) the negative effects of age at migration on national self-identification (e.g., education, length of stay, language, contacts) are included in the model, the 'remaining effect' of age at migration on national self-identification becomes positive and significant. 


\section{References}

Alba, R., \& Nee, V.

1997 "Rethinking Assimilation Theory for a New Era of Immigration." International Migration Review 31:826-74.

Ashmore, R., Deaux, K. \& McLaughlin-Volpe, T.

2004 "An organizing framework for collective identity: Articulation and significance of multidimensionality." Psychological Bulletin 130:80-114.

Baron, R. M., \& Kenny, D. A.

1986 "The moderator-mediator variable distinction in social psychological research: Conceptual, strategic, and statistical considerations." Journal of Personality and Social Psychology, 51:1173-1182.

Berry, J.W.

1997 "Immigration, acculturation and adaptation." Applied Psychology: An International Review 46:5-68.

Branscombe, N.R., Schmitt, M.T. \& Harvey, R.D.

1999 "Perceiving pervasive discrimination among African Americans: Implications for group identification and well-being." Journal of Personality and Social Psychology 77:135-149.

Colic-Peisker, V.

2009 "Visibility, Settlement Success and Life Satisfaction in Three Refugee Communities in Australia." Ethnicities 9:175-199.

Connor, $\mathrm{P}$.

2010 "Explaining the Refugee Gap: Economic Outcomes of Refugees versus Other Immigrants." Journal of Refugee Studies 23:377-397.

De Vroome, T. \& Van Tubergen, F.

2010 "The Employment Experience of Refugees in the Netherlands." International Migration Review 44:376-403.

Fozdar, F. \& Torezani, S.

2008 "Discrimination and Well-Being: Perceptions of Refugees in Western Australia." International Migration Review 42:30-63.

Friedberg, R. M.

2000 "You Can't Take It With You? Immigrant Assimilation and the Portability of Human Capital." Journal of Labor Economics 18:221-251.

Ganzeboom, H.B.G., De Graaf, P.M. \& Treiman, D.J.

1992 "A Standard International Socio-Economic Index of Occupational Status." Social Science Research 21:1-56.

Gijsberts, $\mathrm{M}$.

2005 "Opvattingen van Autochtonen en Allochtonen over de Multi-Etnische Samenleving." In: SCP, WODC \& CBS (Eds.), Jaarrapport Integratie 2005. Den Haag: SCP, WODC, CBS.

Gordon, M.M.

1964 Assimilation in American life. London: Oxford University Press.

Hagendoorn, L., Veenman, J. \& Vollebergh, W. (Eds.) 
2003 Integrating Immigrants in the Netherlands: Cultural versus Socio-Economic Integration. Aldershot: Ashgate.

Hovy, B. \& Chabake, T.A.

20052003 UNHCR Statistical Yearbook. Geneva: UNHCR.

Hwang, S. \& Murdock, S.

1991 "Ethnic Enclosure or Ethnic Competition: Ethnic Identification among Hispanics in Texas." Sociological Quarterly 23:469-476.

Jasinskaja-Lahti, I., Liebkind, K. \& Solheim, E.

2009 "To Identify or Not To Identify? National Disidentification as an Alternative Reaction to Perceived Ethnic Discrimination." Applied Psychology - International Review 58:105-128.

Kanas, A. \& Van Tubergen, F.

2009 "The Impact of Origin and Host Country Schooling on the Economic Performance of Immigrants." Social Forces 88:893-915.

Koopmans, R.

2003 "Good Intentions Sometimes Make Bad Policy. A Comparison of Dutch and German Integration Policies." In: R. Cuperus, et al. (Eds.), The Challenge of Diversity. European Social Democracy Facing Migration, Integration, and Multiculturalism. Innsbruck: Studienverlag, 47-58.

Lamba, N. K.

2003 "The Employment Experiences of Canadian Refugees: Measuring the Impact of Human and Social Capital on Quality of Employment." Canadian Review of Sociology and Anthropology 40:45-64.

Lubbers, M. J., Molina, J. L., \& McCarty, C.

2007 "Personal Networks and Ethnic Identifications - the Case of Migrants in Spain." International Sociology 22:721-41.

Nagelkerke, N.J.D.

1991 "A Note on a General Definition of the Coefficient of Determination." Biometrika 78:691-692.

Nafziger, E.W., Stewart, F. \& Vayrynen, R. (Eds.)

2000 War, hunger and displacement: the origin of humanitarian emergencies. Oxford: Oxford University Press.

Nesdale, D.

2002 "Acculturation Attitudes and the Ethnic and Host-Country Identification of Immigrants." Journal of Applied Psychology 32:1488-1507.

Ono, $\mathrm{H}$.

2002 "Assimilation, Ethnic Competition, and Ethnic Identities of US-born Persons of Mexican Origin." International Migration Review 36:726-745.

Phinney, J.S.

1990 "Ethnic Identity in Adolescents and Adults: Review of Research." Psychological Bulletin 108:499-514.

Schothorst, Y.

2004 SPVA-2003. Verslag van het veldwerk onder vijf groepen allochtonen. Amsterdam: Veldkamp. 
Tajfel, H. \& Turner, J.C.

1986 "The social identity theory of intergroup behaviour." In: S. Wörchel \& W. Austin (Eds.), The social psychology of intergroup relations. Pacific Grove: Brooks/Cole (pp. 33-48).

Verkuyten, $\mathrm{M}$.

2005 The Social Psychology of Ethnic Identity. Hove: Psychology Press.

Verkuyten, M. \& Yildiz, A.A.

2007 "National (Dis)identification and Ethnic and Religious Identity: A Study Among Turkish-Dutch Muslims.” Personality and Social Psychology Bulletin 33:1448-1462.

Walters, D., Phythian, K. \& Anisef, P.

2007 "The Acculturation of Canadian Immigrants: Determinants of Ethnic Identification with the Host Society." Canadian Review of Sociology and Anthropology 44:37-65.

Waxman, P.

2001 "The Economic Adjustment of Recently Arrived Bosnian, Afghan and Iraqi Refugees in Sydney, Australia." International Migration Review 35:472-505.

Zimmermann, L., Zimmermann, K. \& Constant, A.

2007 "Ethnic Self-Identification of First-Generation Immigrants." International Migration Review 41:769-781. 